1975

\title{
An Archaeological Survey of the Upper Cibolo Creek Watershed, Central Texas
}

Feris A. Bass, Jr.

Thomas R. Hester

Center for Archaeological Research

Follow this and additional works at: https://scholarworks.sfasu.edu/ita

Part of the American Material Culture Commons, Archaeological Anthropology Commons, Environmental Studies Commons, Other American Studies Commons, Other Arts and Humanities Commons, Other History of Art, Architecture, and Archaeology Commons, and the United States History Commons

Tell us how this article helped you.

This Article is brought to you for free and open access by the Center for Regional Heritage Research at SFA ScholarWorks. It has been accepted for inclusion in Index of Texas Archaeology: Open Access Gray Literature from the Lone Star State by an authorized editor of SFA ScholarWorks. For more information, please contact cdsscholarworks@sfasu.edu. 


\section{An Archaeological Survey of the Upper Cibolo Creek Watershed, Central Texas \\ Creative Commons License \\ (c) () () (9)}

This work is licensed under a Creative Commons Attribution-NonCommercial 4.0 International License 


\section{An Archacological Surver of the}

\section{Upper Cibolo Creek,Watershed, Central Texas}

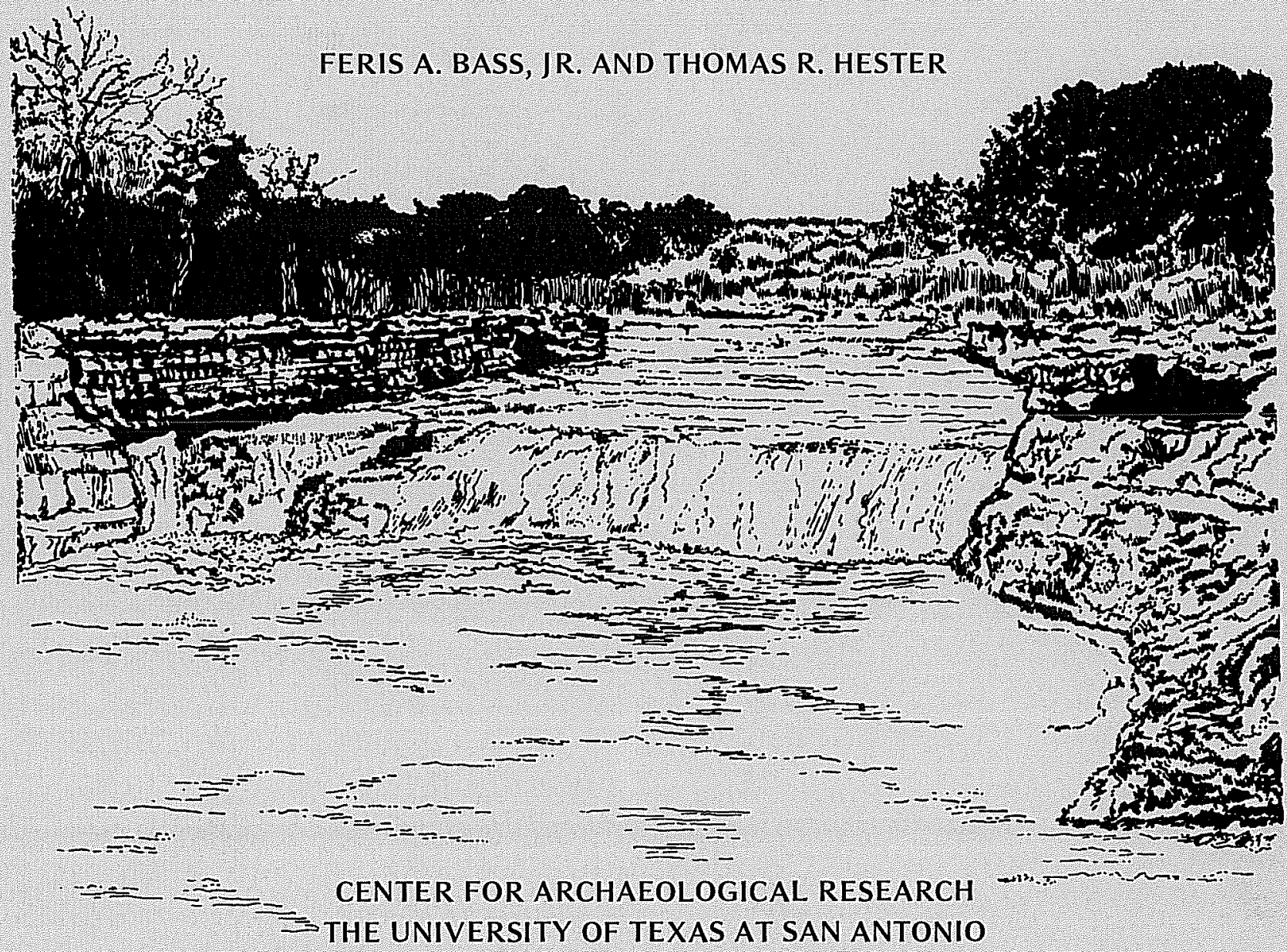

ARCHAEOLOGICAL SURVEY REPORT, NO. 8

MARCH, 1975 
AN ARCHAEOLOGICAL SURVEY OF THE UPPER CIBOLO

CREEK WATERSHED, CENTRAL TEXAS

Feris A. Bass, Jr. and Thomas R. Hester

Center for Archaeological Research The University of Texas at San Antonio Archaeological Survey Report, No. 8

March, 1975 
TABLE OF CONTENTS

$\begin{array}{lc} & \text { Page } \\ \text { Introduction } & 1 \\ \text { Archaeological Background } & 3 \\ \text { Survey Procedures } & 5 \\ \text { Results of the Survey } & 5 \\ \text { Evaluation of Resources } & 29 \\ \text { Summary } & 34 \\ \text { References Cited } & 37\end{array}$


Figures

1. Archaeological Sites in the Upper Cibolo Creek Watershed

2. Archaeological Sites in the Upper Cibolo Creek Watershed

3. Two Historic Sites in the Upper Cibolo Creek Watershed

4. Two Prehistoric Sites in the Upper Cibolo Creek Watershed

5. Upper Cibolo Creek Watershed: Views

6. Upper Cibolo Creek Watershed: Projectile Points

7. Upper Cibolo Creek Watershed: Bifacial and Unifacial Artifacts

Tables

1. Provenience of Artifacts Collected at Site $41 \mathrm{KE} \mathrm{49,} \mathrm{Upper}$ Cibolo Creek Watershed

2. Recommendations for Future Archaeological Investigation in the Upper Cibolo Creek Watershed

3. Impact of Proposed Floodwater Retarding Structures on Archaeological and Historic Resources 


\section{INTRODUCTION}

During February, 1975, the Center for Archaeological Research at The University of Texas at San Antonio carried out an archaeological survey of the Upper Cibolo Creek Watershed in Kendall County, Texas. The Soil Conservation Service of the United States Department of Agriculture proposes to construct four floodwater retarding structures on upper Cibolo Creek and three of its tributaries (Ranger Creek, Frederick Creek, and Deep Hollow Creek) and the purpose of the archaeological survey was to provide an assessment of the historic and prehistoric cultural resources in these areas. The field work was conducted under the terms of a contract (AG-48-scs-02539) with the Soil Conservation Service, in which five major survey objectives were outlined:

1. Determine if archaeological resources exist within the area committed to installation of each floodwater retarding structure.

2. If resources are found, record, identify, and appraise the significance of resources including apparent eligibility for nomination to the National Register of Historic Places.

3. Evaluate the impact of project installation on each resource.

4. Provide recommendations for mitigation of adverse impacts anticipated.

5. Provide estimate of costs required for mitigation (salvage, protection, etc.). 
Kendall County is located in south central Texas, in the southern portion of the Edwards Plateau (Sellards, Adkins and Plummer 1932). The terrain is characteristica11y rough with extensive surface exposures of Edwards 1imestone (cf. Edwards Underground Water District, n.d.: 2). The two major stream drainages are the Guadalupe River in central Kendall County, and Cibolo Creek to the south. Blair (1950) has included the area in his Balconian biotic province; additional data on the region's vegetation and fauna can be found in Gould (1969) and Dabney (1952). The local soils are of the Tarrant-Brackett-Speck series (cf. Godfrey, McKee and Oakes 1973). An earlier description of the region's soils is provided by Kocher et al (1913). Rose (1972) has studied the subsurface geology of western Kenda11 County.

Brief summaries of the topography and vegetation patterns within each proposed project area are presented later. In general, the uplands are rugged expanses of limestone, with sparse vegetation consisting of scrub cedar, blackjack, live oak, shin oak, post oak and short grasses. The flood plains and terraces are usually more heavily vegetated, except, of course, in those areas cleared for cultivation. Major vegetation forms found in terrace-floodplain locales include live oak, persimmon, black walnut, mulberry pecan, mesquite, prickly pear (and occasional yucca), and tall to mid grasses. In the riparian environs along the stream courses, vegetation becomes considerably more dense, dominated by 1ive oak, persimmon, walnut, and vines.

For information on the history of Kendall County, the reader is referred to Dabney (1952), Jenkins (1965) and Hester (1975). 


\section{ARCHAEOLOGICAL BACKGROUND}

At the time this survey was initiated, 24 archaeological sites had been formally recorded in Kenda11 County. Two additional sites have since been reported in the Guadalupe River drainage by Hester, Kelly and Bass (1975) and several others have been noted in western Kendall County by W. Fawcett (personal communication). A brief summary of the archaeology of the county appears in Hester (1975).

Although the sample of sites is small, several kinds of sites are known to be present in the area. These include burned rock middens, open occupation sites, buried terrace sites, rockshelters (see Briggs 1970), quarry/workshops, and lithic scatters. Most of the sites apparently date from the Archaic (ca. 6000 B.C. to A.D. 500/1000) and Late Prehistoric (Neo-American; A.D. 500/1000-1600) periods of central Texas prehistory. Scattered finds of projectile points dating from Paleo-Indian times (9200-6000 B.C.), particularly the latter part of that period, have been documented (Enlow and Campbell 1955; W. Farcett, notes on 41 KE 10; T.C. Kelly, notes on $41 \mathrm{KE} \mathrm{23).}$

In that portion of Kendall County in which our survey was concentrated, two groups of sites have been previously recorded. One group, $41 \mathrm{KE} \mathrm{3-9} \mathrm{(the} \mathrm{Less} \mathrm{Ranch} \mathrm{sites),} \mathrm{are} \mathrm{on} \mathrm{the} \mathrm{upper} \mathrm{Frederick}$ Creek drainage, above the area of Floodwater Retarding Structure No. 3. Another cluster of sites have been noted by $W$. Fawcett (personal communication) on Little Joshua Creek, a tributary of Cibolo Creek. This area is to the northwest of proposed Floodwater 
Retarding Structure No. 1. The sites found by Fawcett include open occupation sites (Fawcett's Sites 1 and 5; there is a possible burned rock midden at Site 1), small lithic scatters (his Sites 2 and 3), a large lithic workship (Site 4), and caves and rockshelters containing prehistoric occupational deposits (Sites 6-8). A previous site reported by Fawcett is $41 \mathrm{KE} \mathrm{10,} \mathrm{a} \mathrm{burned} \mathrm{rock}$ midden site near the confluence of Allan and Little Joshua Creeks, roughly $6 \mathrm{~km}$ north of Floodwater Retarding Structure No. 1. Test excavations by Fawcett indicated that the site was largely attributable to the Late Archaic, although a Neo-American component was found on one edge of the site area. Notes by Fawcett on file at the Texas Archeological Research Laboratory indicate the occurrence of Angostura and Early, Middle and Late Archaic dart points. 


\section{SURVEY PROCEDURES}

Prior to beginning the field work, the survey team contacted Mr. Harold Coffee, SCS District Conservationist at Boerne, Texas. Mr. Coffee was of invaluable assistance in securing landowner permission for entry into the proposed project areas.

Through the cooperation of the Texas Archeological Research Laboratory at The University of Texas at Austin, the survey personnel were able to determine that no archaeological resources had been previously recorded within the specific areas slated for inspection. However, the information on nearby sites provided us by W. Fawcett, Jr., served as an indication of the kinds of archaeological remains that might be expected in the vicinity.

Our surveys were conducted on foot and entailed a close inspection of the terrain that would be affected by the proposed structures and resulting detention, conservation and 100-year sediment pools. A total of 399.8 hectares (987.6 acres) was surveyed. As sites were discovered, a site survey form was filled out and site locations were plotted on a U.S.G.S. topographic map (the Ranger Creek 7.5' sheet). Although surface collections were made at several of the sites, most were subjected to limited surface sampling in order to provide data which would aid in the assessment process.

$$
\text { RESULTS OF THE SURVEY }
$$

Thirty-three archaeological sites were documented during survey activities in the Upper Cibolo Creek Watershed. In this section, the area of each proposed floodwater retarding structure is 
described and brief summaries are provided of sites found within each project area. Site locations are shown in Figs. 1 and 2. Floodwater Retarding Structure No. 1

The area encompassed by this structure lies between Upper Cibolo Road and Ranger Creek Road approximately $5.6 \mathrm{~km}$ west of Boerne, Texas and extends a distance of approximately $3.2 \mathrm{~km}$ further west along Cibolo Creek. The total area encompassed by this project is 215 ha (530.6 acres). The southern border of the reservoir is bounded by a range of hills and steep bluffs. The northern border is a more gradually sloping plain which is mostly under cultivation.

The immediate flood plain of the creek is covered with moderately heavy vegetation consisting primarily of live oak and cedar. A large portion of this area was covered with a dense growth of grass which effectively obscured the ground and somewhat hindered inspection of this area. Nonetheless, our survey of this proposed structure recorded 19 archaeological and historical sites. 
This page has been

redacted because it

contains restricted

information. 
This page has been

redacted because it

contains restricted

information. 
Prehistoric and historic resources found during the survey are summarized below:

Site Number

$41 \mathrm{KE} 25$

$41 \mathrm{KE} 26$

$41 \mathrm{KE} 27$
Description

Site is situated on a high bluff overlooking the southern end of the proposed dam and covers an area of approximately $100 \mathrm{~m}$ by $30 \mathrm{~m}$. A moderately heavy concentration of chert flakes and debitage was observed. Some flakes showed evidence of having been worked. The site was covered with grass, scrub brush, and a few live oak and cedar trees.

Site is situated on the second stream terrace on the south bank of Cibolo Creek approximately $610 \mathrm{~m}$ west of the proposed dam. The east end of the site is covered with grass, live oak and some cedar. The center of the site is a cultivated field. Most of the archaeological material, consisting of lithic materials (flakes and bifaces) was found in the live oak grove on the eastern border. Inspection was hampered by the grass cover. Site is roughly circular, approximately $100 \mathrm{~m}$ in diameter.

Site is located on the center line of the proposed dam at the north bend of the Cibolo Creek. This is on a bluff paralleling Cibolo Creek as it turns south at the dam site and is on the south slope of a ridge that extends east perpendicular to the stream course. The area is covered with live oaks, cedar and heavy grass. The site is approximately $25 \mathrm{~m}$ in diameter. Archaeological materials consist of thinly scattered chert flakes, cores and a cluster of burned rocks, possibly the remains of a hearth.

None

None
Material Collected

1 scraper

1 bifacial preform 
Site Number

$41 \mathrm{KE} 43$

(Fig. 3,b)

$41 \mathrm{KE} 29$

$41 \mathrm{KE} 30$
Description

Site is on bluff at bend of Cibolo Creek at the north end of the north-south portion of the dam and consists of an old stone and wood building, now in ruins. One wal1 still stands and only the outline of the foundation remains for the other part. The floor area was littered with chert flakes, parts of artifacts, and a projectile point. In addition, there is much historic material, such as a portion of an old coffee grinder, square nails, crockery, etc. There were also some bone fragments present.

Site is approximately $100 \mathrm{~m}$ northwest of site $41 \mathrm{KE} 43$ and is a scatter of lithic materials consisting of chert flakes, bifaces and a few cores. The concentration of 1ithic debris is light and the site is only about $10 \mathrm{~m}$ in diameter.

Site is $800 \mathrm{~m}$ west of northsouth centerline of dam on a steep slope on the north bank of Cibolo Creek, approximately $150 \mathrm{~m}$ from creek channel and about $30 \mathrm{~m}$ above creek bed. Site dimensions are $50 \times 100 \mathrm{~m}$, paralleling the stream course (east-west). Site is covered with moderately heavy vegetation consisting of live oak, cedar and grass. At the time of survey, there was a heavy accumulation of leaves which obscured the ground and hindered observation. There was a heavy scatter of lithic materials consisting of flakes, cores and burned rock. All visible materials were collected.
Materia1 Collected

1 stemmed dart point

1 Nolan point

5 cortex flakes

4 thinning flakes

1 exausted core

9 fragments firecracked rock

1 mussel shell

2 metal buttons

1 pearl button

2 hatchet blades

1 hair comb

1 piece broken crockery

1 clothes pin

3 pieces animal bone

Assorted pieces of broken glass

Numerous square nails

$1.45-.70$ rifle cartridge

Assorted pieces of china

1 leatherstrap w/buckle

None

3 cores

2 side scrapers

3 end scrapers

1 biface preform fragment

16 chert flakes

4 fire-cracked chert pieces 
Figure 3. Two Historic Sites in the Upper Cibolo Creek Watershed. a, stone ruins at $41 \mathrm{KE} 45$ (looking south); b, house floor at $41 \mathrm{KE} \mathrm{43,} \mathrm{littered} \mathrm{with} \mathrm{debris,} \mathrm{including} \mathrm{historic} \mathrm{and} \mathrm{prehistoric}$ materials (note dart point in the middle of the picture) 


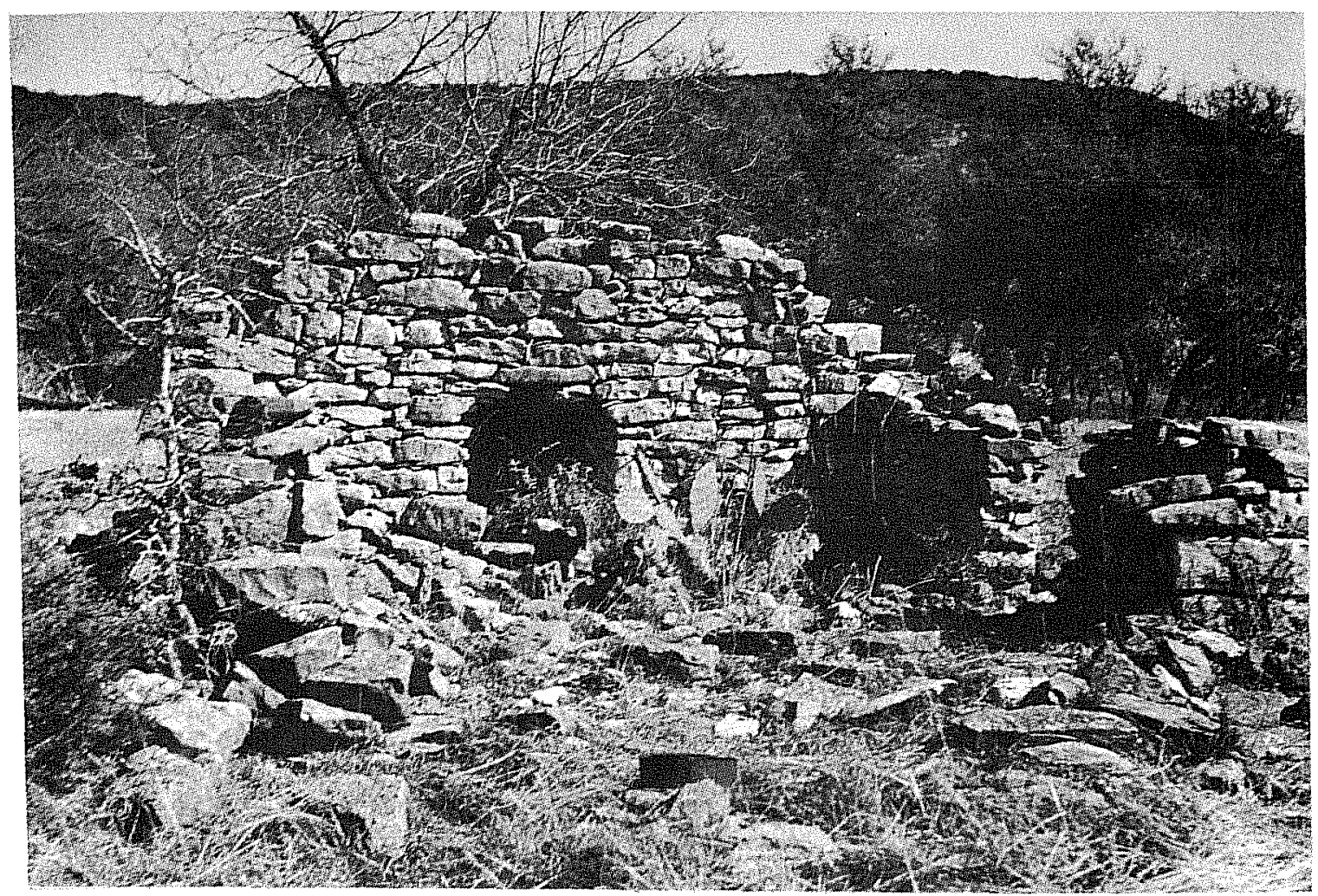

a

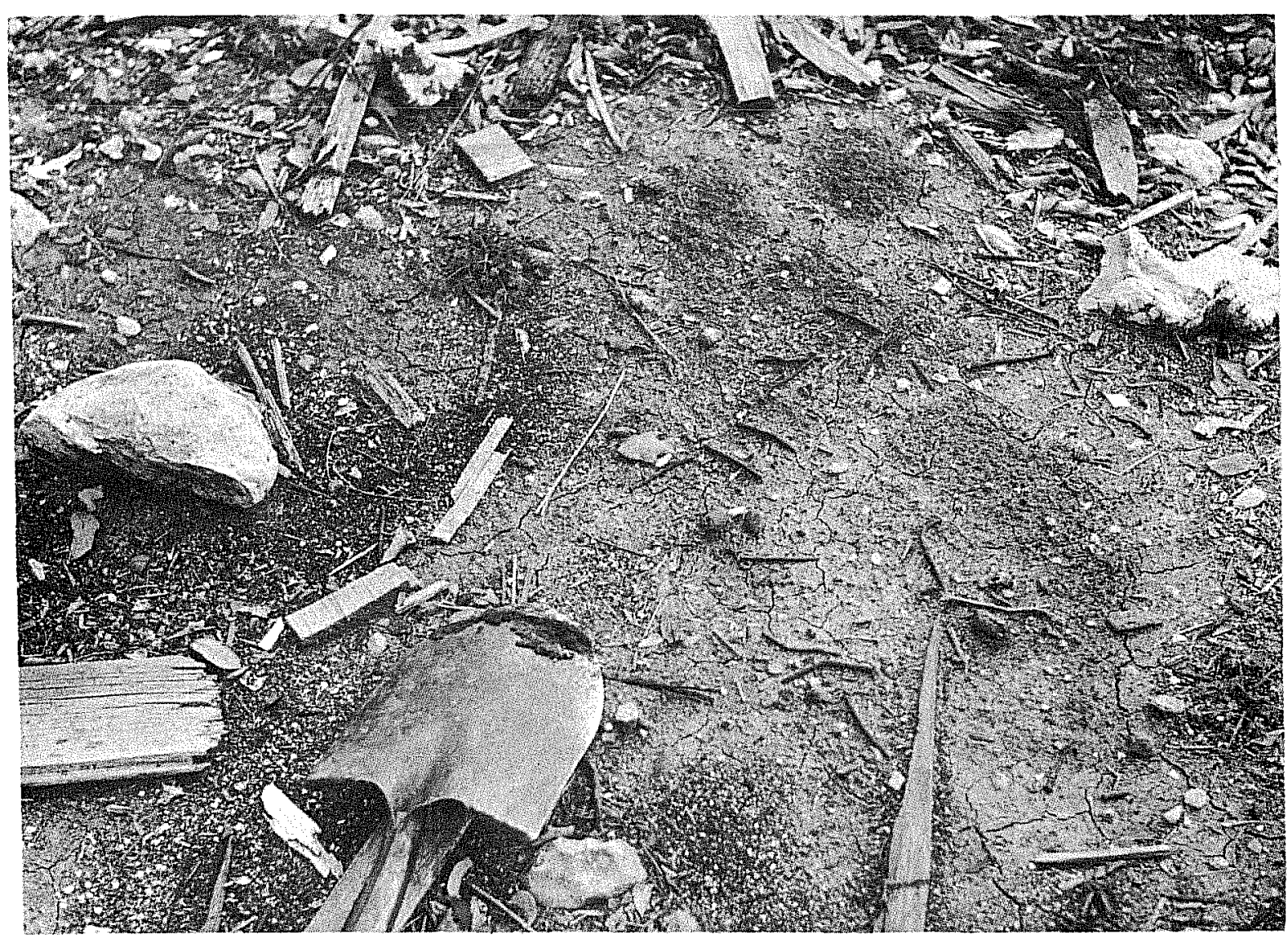


Site Number

$41 \mathrm{KE} 31$

$41 \mathrm{KE} 32$

$41 \mathrm{KE} 33$

$41 \mathrm{KE} 34$
Description

Site immediately adjoins site $41 \mathrm{KE} 30$ to the west and may even be a continuation of that site. The character of this site is identical to its neighbor.

Site is located $1800 \mathrm{~m}$ west of north-south centerline of dam in the edge of a plowed field paralleling the eastern arm of the ox-bow bend of Cibolo Creek. The site is approximately $300 \mathrm{~m}$ long and $10 \mathrm{~m}$ wide and extends out into the plowed field. The disturbed nature of the ground could well have obscured the true extent of the site. Archaeological materials observed included chert flakes and one projectile point.

Site is immediately north of site $41 \mathrm{KE} 31$ and is probably a continuation of that site. It is approximately $75 \mathrm{~m}$ in diameter and is situated in and along a deep wash in a plowed field. The erosion had exposed a rather heavy lithic scatter which included chert flakes, points and cores. Al1 materials in a $30 \mathrm{~m}$ circle at the center of the site were collected.

Site adjoins site $41 \mathrm{KE} 33$ to the north and extends to the curve of the bend of the ox-bow turn in the creek. It is approximately $100 \mathrm{~m} \mathrm{x}$ $30 \mathrm{~m}$. There is a band of brush and live oak trees that border the stream but the site is in the plowed field. The lithic scatter in this site is somewhat less than that observed in site $41 \mathrm{KE} 33$ but may be due to the lack of erosional activity. Flakes, chips and cores were evident here in moderately heavy concentrations.
Material Collected

1 Ensor point

1 triangular bifacial preform

1 small ovate scraper

2 cortex flakes

3 thinning flakes

None

2 stemed dart points

3 ovate preform fragments

1 Abasolo dart point

2 distal point fragments

2 medial point fragments

1 basal point fragment

7 cores

4 choppers

2 bifacial preforms

1 scraper

36 cortex flakes

89 interior flakes

None 
Site Number

$41 \mathrm{KE} 35$

$41 \mathrm{KE} 36$

$41 \mathrm{KE} 37$

$41 \mathrm{KE} 48$

\section{Description}

Site covers an area of $100 \mathrm{x}$ $30 \mathrm{~m}$ and is in the same plowed field as those above except that it is in the eastern part of that field and is adjacent to a heavily vegetated drainage that cuts across the field. The site borders the eastern edge of this swale and could conceivably form a continuation of site $41 \mathrm{KE} 31$ $300 \mathrm{~m}$ southeast. The site is covered with lithic materials.

Site immediately adjoins site $41 \mathrm{KE} 35$ to the east in a grove of trees paralleling the Cibolo stream course. It is approximately $300 \mathrm{~m}$ long and $10 \mathrm{~m}$ wide. Chert concentration on this site is lighter than on site $41 \mathrm{KE} 35$.

Site is an historical burial plot enclosed with a wire fence, $3 \mathrm{~m} \mathrm{x}$ $5 \mathrm{~m}$. Plot is heavily overgrown and no evidence exists at the site of the identicy of those persons buried here. It is possible that this is the burial area for the inhabitants of the building at site $41 \mathrm{KE} 43$. The cemetery is presently on the property of H. B. Fuqua.

Site covers an area $100 \mathrm{~m} \times 300 \mathrm{~m}$ (north-south), and is $300 \mathrm{~m}$ west of western arm of ox-bow bend of Cibolo Creek and borders the road paralleling the creek west of the ox-bow. It is in a plowed field and is centered in a grove of live oaks and cedar trees on a low knoll in the center of the field. Lithic materials included chert flakes, cores and burned rock. There was a well defined hearth in the eastern edge of the grove of trees. The heaviest concentration of lithic materials occurred on the southern end of the site.
Materia1 Collected

1 corner notched dart point

2 chert flakes.

1 point fragment

None

1 end scraper

2 biface preforms

1 medial point fragment

1 distal biface fragment

1 basal point fragment

1 core 
Site Number

$41 \mathrm{KE} 52$

(Fig. 5,a)

$41 \mathrm{KE} 53$

$41 \mathrm{KE} 49$

$41 \mathrm{KE} 50$
Description

Site is on a bluff at the base of the western edge of the oxbow bend of the Cibolo Creek on the inside of the ox-bow. The side is covered with cedar, live oak, agave and a moderately heavy grass cover. Lithic materials occur here in an area $50 \mathrm{~m} \times 100 \mathrm{~m}$, and include cores, flakes, some bifaces and burned rock. There is also an indication of a hearth. The site is relatively undisturbed.

This is a rather light lithic scatter on the outside bend of the ox-bow of Cibolo Creek. The extremely heavy vegetation cover, consisting of live oak, cedar and grass, impaired our ability to examine the area. Very little lithic material was found but it is felt that under more favorable conditions, a better evaluation could be made.

This is by far the richest site, in terms of surface lithics, found on this survey. It is located in a plowed field on the west bank of the east leg of the ox-bow bend of Cibolo Creek. It encompases an area of $150 \mathrm{~m} \mathrm{x} 300 \mathrm{~m}$ parallel to the stream course. There is an extremely heavy concentration of lithic materials consisting of flakes, preforms, bifaces and some point fragments, and burned rock. The site was collected by five transects, each $1 \mathrm{~m}$ wide and placed $15 \mathrm{~m}$ apart.

Located at the base of a slope terminating at the point of land projecting into the oxbow of Cibolo Creek, midway
Material Collected

None

None

See Table 1

1 Tortugas point 
Site Number

between the western and eastern

legs of the creek. The surface

of the site area was covered with

grass, cedar, live oak and scrub

oak. For this reason on $1 y$ a

few lithic materials were seen

here.

$41 \mathrm{KE} 51$

This is the location of an old historic structure which was demolished in 1913 according to the present owner of the land. There is little left of the structure but there is a quantity of historical material strewn about the site, including square nails, crockery and bits of iron of indeterminate origin. The site is located on a stream terrace on the south bank of the Cibolo Creek, approximately $750 \mathrm{~m}$ west of the north-south center line of the proposed dam.

1 fragment of corn grinder

13 glass fragments (glass, bottle, and window pane)

6 fragments of china ware

1 chert cortex flake

1 mason jar cup

7 square nails

Floodwater Retarding Structure No. 2

This structure is planned for construction on Ranger Creek

$3.9 \mathrm{~km}$ due west of Interstate Highway 10 and $300 \mathrm{~m}$ south of Ranger

Creek Road. A total of 30 ha ( 74 acres) will be involved. The area slated for the project is a wide, open valley situated between two ranges of hills rising steeply on both sides of Ranger Creek. The slopes of these hills are quite rocky and at the time of the survey there were many seeps resulting from recent rains. The slopes of the hills extending almost to the banks of Ranger Creek are dotted with clumps of trees and brush and some grass, 


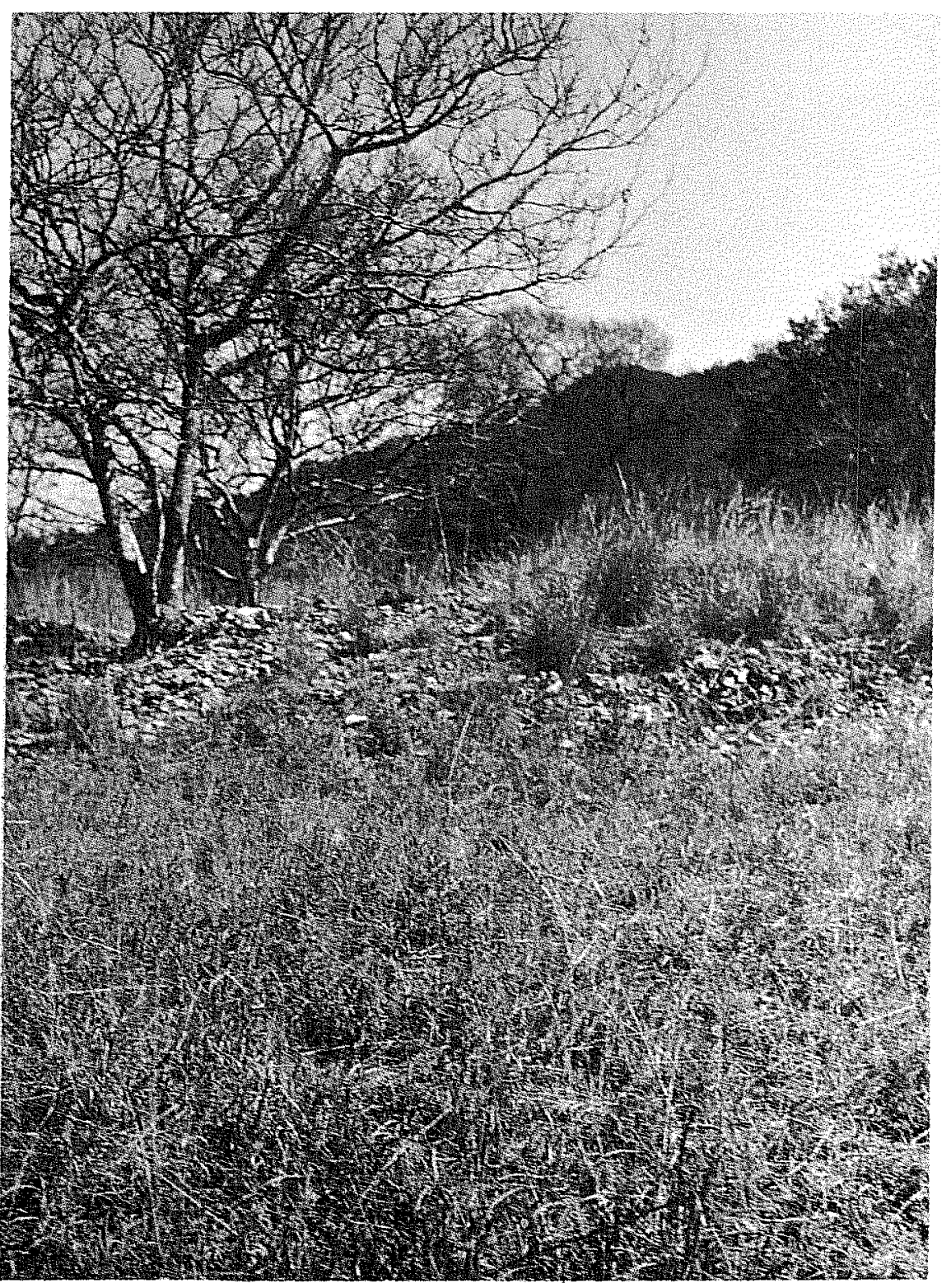

a

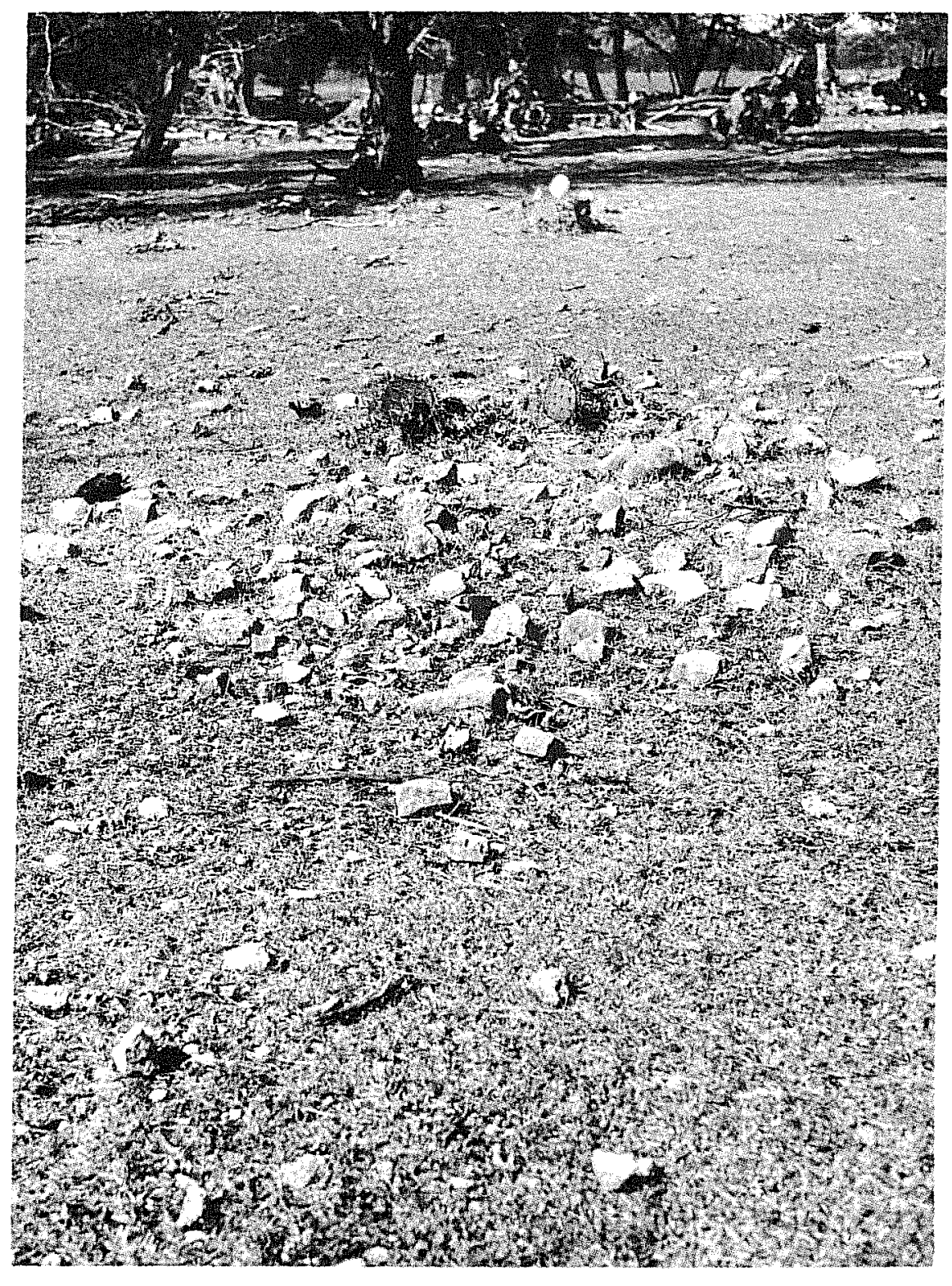

b

Figure 4. Two Prehistoric Sites in the Upper Cibolo Creek watershed. a, burned rock midden at $41 \mathrm{KE} 57$; b, large hearth at $41 \mathrm{KE} 46$ 
while the valley floor was heavily covered with a thick growth of grass. Our survey of this area led to the documentation of three archaeological sites.

Site Number

$41 \mathrm{KE} 38$

$41 \mathrm{KE} 39$

$41 \mathrm{KE} 47$
Description

Located approximately $100 \mathrm{~m}$ west of the upper end of the permanent pond on Ranger Creek just east of the proposed dam at the north bend of Ranger Creek. Site is situated on a point of land overlooking the creek and is roughly circular in shape. It is approximately $20 \mathrm{~m}$ in diameter, heavily covered with grass, with some mesquite, cedar and light brush. Lithic materials consisted of chert flakes and some burned rock all of which were difficult to see because of the heavy ground cover. All visible material was collected.

Located on the north stream terrace above Ranger Creek approximately $750 \mathrm{~m}$ west of the proposed dam center line. A rock outcrop is present along north edge of site. There is a heavy grass cover in the area and only a light concentration of lithic materials was observed.

Site is on the north boundary of project, probably lying partially outside of the highest elevation of the detention pool. A ranch road passes just west of the site. A very light lithic scatter was found in an area approximately $10 \mathrm{~m}$ in diameter.
Material Collected

20 chert flakes

2 fire-fractured flakes
1 basal point fragment

1 burin

1 large side \& end scraper

1 unifacial tool

1 end scraper

6 chert flakes
1 crudely bifaced cobble 
Floodwater Retarding Structure No. 3

This facility will be constructed on Frederick Creek, approximately $4 \mathrm{~km}$ west of Interstate Highway 10 and will be located between Johns Road and Texas Highway 46. The 85 ha (210 acres) of the proposed reservoir are bordered on the south by a range of hills which rise over $60 \mathrm{~m}$ above the Frederick Creek valley floor. The northern side is a gradually rising plain which increases in elevation only $18 \mathrm{~m}$ in $600 \mathrm{~m}$. In the center of the proposed reservoir there now exists a permanent lake, Lake $0 z$, some $800 \mathrm{~m}$ in length. Some portions of the valley are covered with a rather heavy growth of vegetation including live oak, cedar, persimmon, yucca and prickly pear and other trees and shrubs. Some land is under cultivation and other sections are grassy pasture land. Nine sites were identified within the confines of this proposed structure.

Site Number

$41 \mathrm{KE} 40$

$41 \mathrm{KE} 41$

$41 \mathrm{KE} 42$
Description

Located at the north end of the proposed dam on a bluff overlooking Frederick Creek. Site is approximately $50 \mathrm{~m}$ in diameter and roughly circular in shape. Lithic materials were scattered and all observed materials were collected.

A small site approximately $20 \mathrm{~m}$ in diameter with a light scatter of chert flakes. Located approximately $200 \mathrm{~m}$ due west of site $41 \mathrm{KE} 40$ in an open field overlooking creek valley.

A small site approximately $10 \mathrm{~m}$ in diameter located in an open grassy field $30 \mathrm{~m}$ north west of a fence corner north east of Lake $\mathrm{Oz}$. Lithic materials consisted of a few chert flakes which were not collected.

\section{Material Collected}

1 Bulverde point

1 bifacial preform

2 side scrapers

2 core fragments

7 chert flakes

2 fire fractured flakes

2 cores

7 chert flakes

None 
Figure 5. Upper Cibolo Creek watershed: Views. a, Site $41 \mathrm{KE} \mathrm{42,}$ with Cibolo Creek on the right; b, Cibolo Creek in the vicinity of Floodwater Retarding Structure No. 1. 


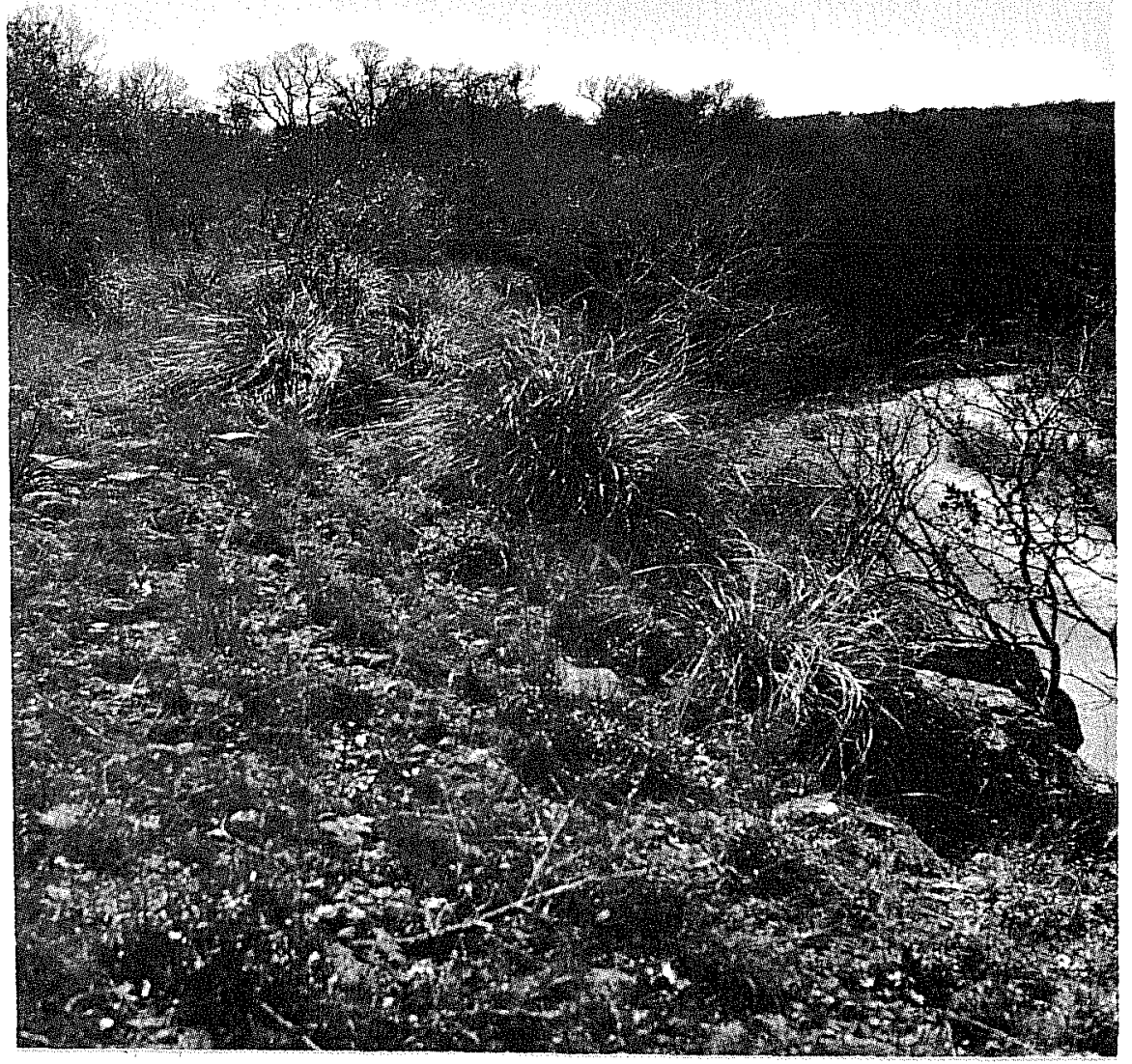

a

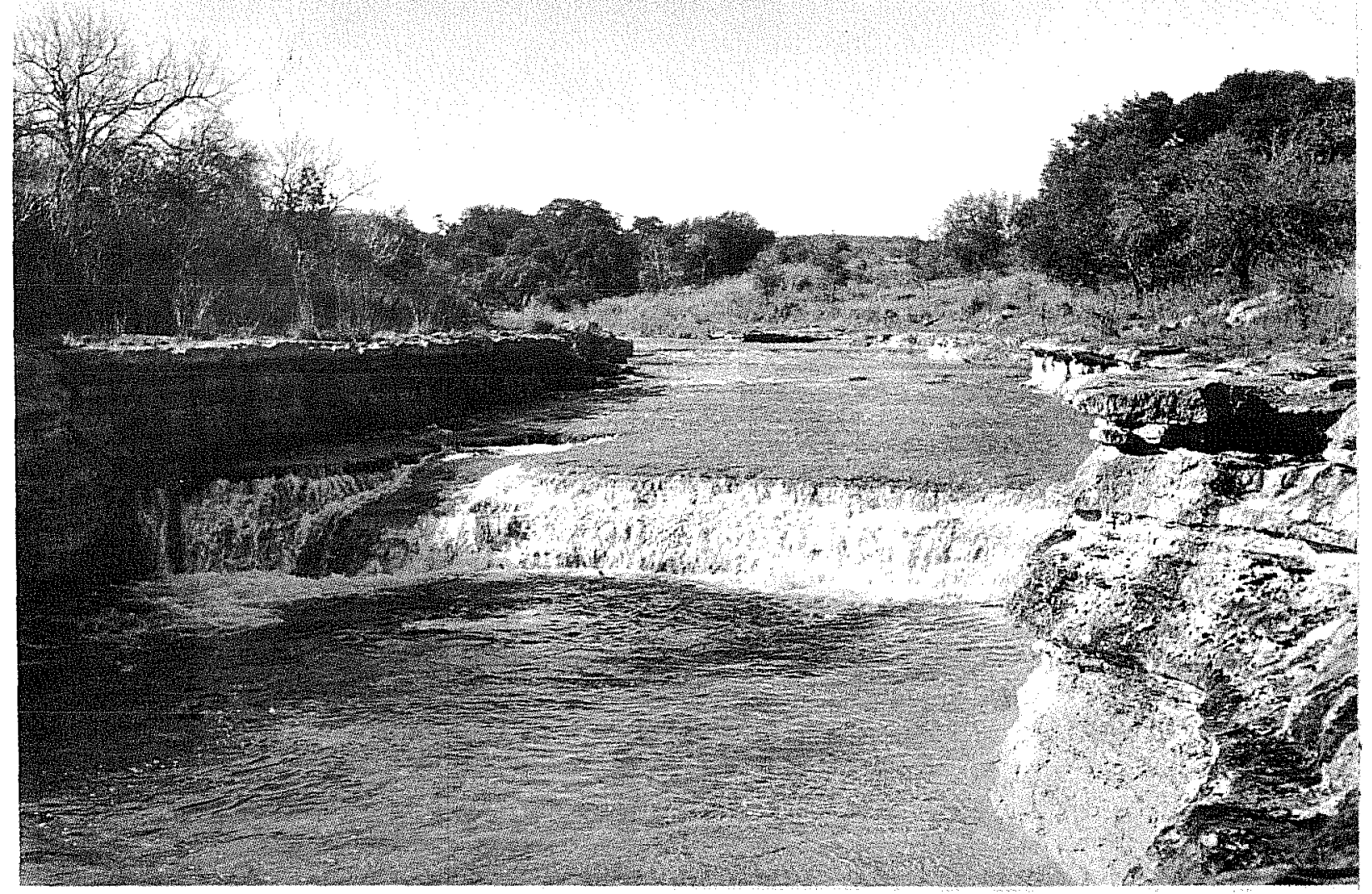


Site Number

$41 \mathrm{KE} 28$

$41 \mathrm{KE} 46$

(Fig. 4,b)

$41 \mathrm{KE} 54$
Description

Located at the upper end of Lake $\mathrm{Oz}$ on the west bank of Frederick Creek just as creek makes northern bend from easterly course as it enters Lake $\mathrm{Oz}$. Site is a rectangular pit $1.5 \mathrm{~m} \times 3.5 \mathrm{~m}$ lined with rocks held in place with mortar. Stone work is in state of ruin with some stones piled outside of pit. The pit is filled with soil and leaf mold much softer than that surrounding the pit. A test hole dug to $50 \mathrm{~cm}$ in pit revealed little but fill and burned rock. No materials were collected.

Located on a grassy terrace at the western edge of the large bend at the upper end of Lake $\mathrm{Oz}$, approximately $120 \mathrm{~m}$ northwest of site $41 \mathrm{KE} 43$. Site is $80 \mathrm{~m} \mathrm{x} 120 \mathrm{~m}$ and rectangular in shape. Abundant lithic materials were present, consisting of chert flakes, points, bifaces, cores, and burned rock. There were several well defined hearths and a partially buried burned rock midden $15 \mathrm{~m}$ in diameter. Site was collected in two north to south transects $15 \mathrm{~m}$ apart and $1 \mathrm{~m}$ in width. All materials within these transects were collected.

Site is located immediately adjacent to the north edge of site $41 \mathrm{KE} 46$ along the upper bend of Frederick Creek. The western edge of both sites is bordered by a plowed field. This site $(20 \mathrm{~m} \times 60 \mathrm{~m})$ is in all probability a continuation of the adjoining site and exhibits many of the characteristics of that site. No collection was made at this site, although a limestone metate $15 \mathrm{~cm} \mathrm{x}$ $30 \mathrm{~cm}$ was found and recorded.
Material Collected

None

\author{
General surface: \\ 1 stemmed dart point \\ 2 distal biface \\ fragments \\ 1 triangular biface \\ basal fragments \\ 2 bifacial preforms \\ Transect 1: \\ 1 bifacial preform \\ 121 chert flakes* \\ Transect 2: \\ 1 biface fragment \\ 1 uniface \\ 290 chert flakes
}

None 
$41 \mathrm{KE} 57$

(Fig. 4,a)

$41 \mathrm{KE} 58$

$41 \mathrm{KE} 59$
Located just east of road crossing on Frederick Creek above Lake $\mathrm{Oz}$, on the south side of the stream. Site is a burned rock midden that has been badly pot-holed and bulldozed. The midden is approximately $45 \mathrm{~m}$ in diameter. A small test pit was dug to examine the stratification in an undisturbed part of the midden. Further testing would be necessary to determine how much of the area is undisturbed.

A small site on the north bank of Lake $\mathrm{Oz}, 30 \mathrm{~m}$ in diameter. Lithic materials observed were burned rock, cores, flakes and bifaces. No collection was made.

Located in an area $500 \mathrm{~m} \mathrm{x} 200 \mathrm{~m}$ along a bluff where Frederick Creek makes a northerly turn below Lake $0 z$. Lithic material included cores, bifaces, flakes and burned rock, all widely scattered throughout the area. No collection was made.
None

None

None 


\section{Floodwater Retarding Structure No. 4}

This structure is 1ocated approximately $375 \mathrm{~m}$ south of Texas Highway 46 on Deep Hollow Creek just before it crosses the highway. The reservoir extends another $625 \mathrm{~m}$ to the south along the creek and encompasses an area of 30 ha (73 acres). The western side of Deep Hollow Creek is a rapidly rising slope. The eastern edge of the reservoir is bounded by a range of hills rising steeply from the stream course. Most of the area within the reservoir and west of the stream course has been under cultivation at some time during the past. There is considerable vegetation in this valley including live oak, cedar, prickly pear, grape vines, and scrub brush of various kinds. Two sites were recorded in the area of this proposed structure.

Site Number

$41 \mathrm{KE} 44$

\section{Description}

This is a lithic scatter in an open, previously cultivated, grassy field. It is on the second stream terrace bordering the western edge of Deep Hollow Creek, $350 \mathrm{~m}$ south of the proposed dam structure. The site is $50 \mathrm{~m} \times 75 \mathrm{~m}$ in area. Lithic material was sparse and consisted primarily of flakes. All observed materials were collected.

This is the ruin of an old, oneroom stone house located at the north end of the field described above. The house is $3.6 \times 4 \mathrm{~m}$ in size, with a partially standing chimney and fire place.
Material Collected

1 Eragmentary Fresno point

16 chert flakes
$41 \mathrm{KE} 45$

(Fig. 3,a) 
Transect 1

1 Tortugas point

1 core

1 chopper

1 biface preform fragment

1 biface preform

2 bifaces

1 biface fragment

2 notched scrapers

1 end scraper

1 side scraper

27 chert flakes

\section{Transect 2}

1 core

1 core-chopper

1 scraper

2 end scrapers

1 side scraper

59 chert flakes
Transect 3

1 biface preform

1 double ended chopper

5 end scrapers

1 side scraper

1 basal point fragment

68 chert flakes

1 uniface preform

2 fire-cracked flakes
Transect 4

1 chopper

2 scrapers

1 side \& end scraper

2 small end scrapers

53 chert flakes

3 fire-fractured rocks

Transect 5

1 Nolan point

1 biface distal fragment

1 biface

3 end scrapers

1 scraper

1 biface fragment

53 chert flakes

Table 1. Provenience of Artifacts Collected at Site 41 KE 49, Upper Cibolo Creek watershed. Artifacts are listed by transect collecting units. 


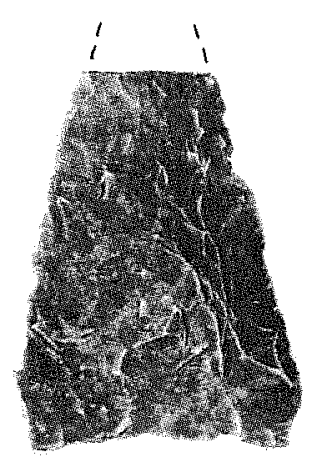

a

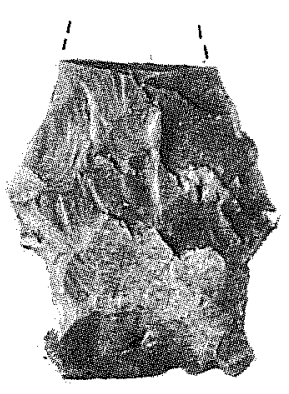

e
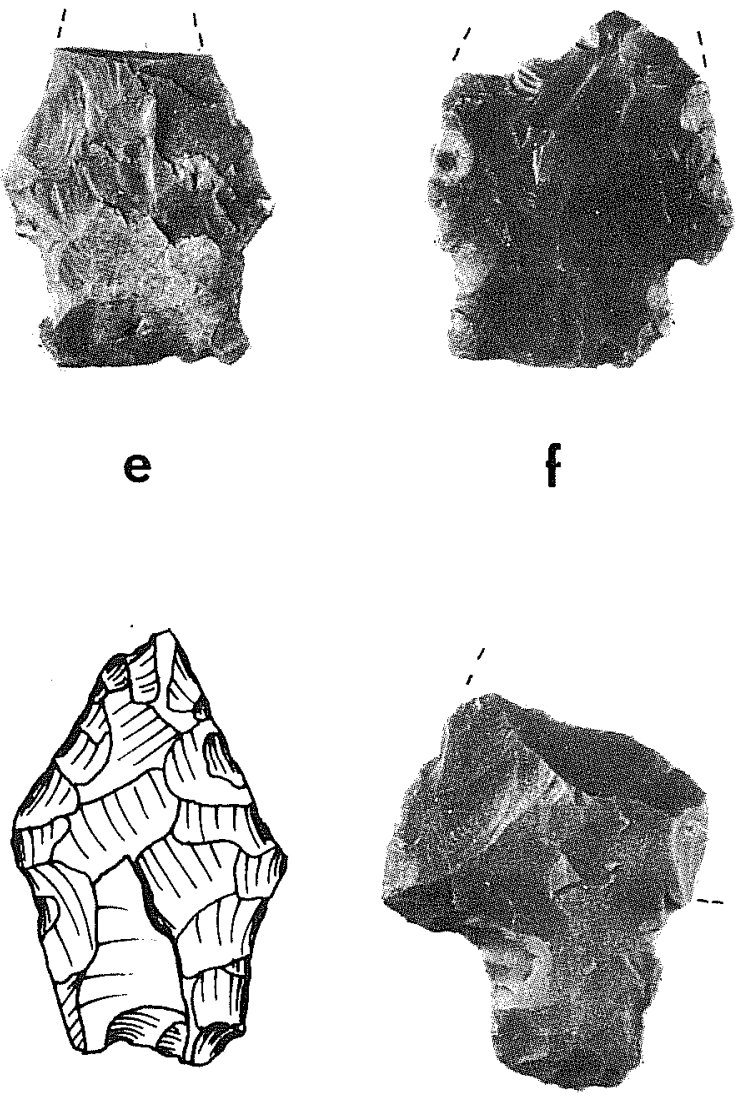

$f$

g

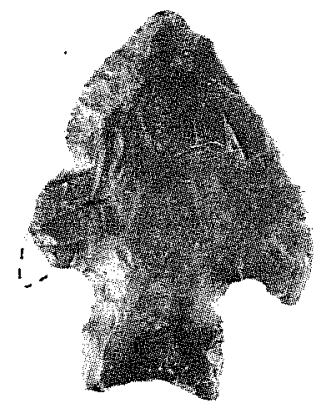

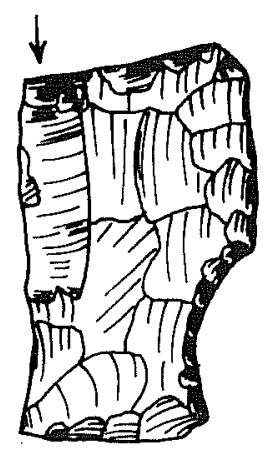

d

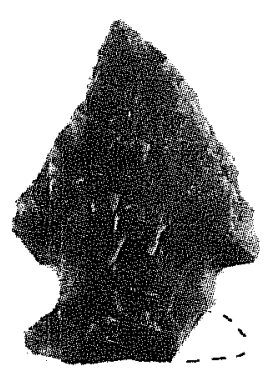

h

$$
\mid \begin{array}{lllllllll|l}
1 & 1 & 1 & 1 & 1 & 1 & 1 & & 1 &
\end{array}
$$

Figure 6. Upper Cibolo Creek Watershed: Projectile Points. a,b, Tortugas (a, $41 \mathrm{KE} \mathrm{49;} \mathrm{b,} 41 \mathrm{KE} \mathrm{50);} \mathrm{c,d,} \mathrm{Nolan} \mathrm{(c,} 41 \mathrm{KE} \mathrm{49;} \mathrm{d,} 41 \mathrm{KE} \mathrm{43);} \mathrm{e-j,}$

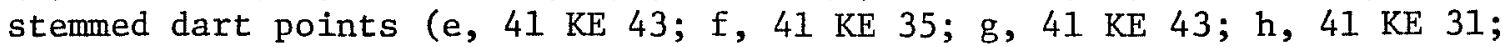
$i, j, 41 \mathrm{KE} \mathrm{33).}$ 
Figure 7. Upper Cibolo Creek Watershed: Bifacial and Unifacial

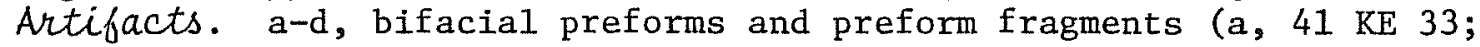
b, $41 \mathrm{KE} \mathrm{49;} \mathrm{c,} 41 \mathrm{KE} \mathrm{31;d,} 41 \mathrm{KE} \mathrm{33);} \mathrm{e-f,} \mathrm{scrapers} \mathrm{(both} \mathrm{are} \mathrm{from}$ $41 \mathrm{KE} \mathrm{49).}$ 

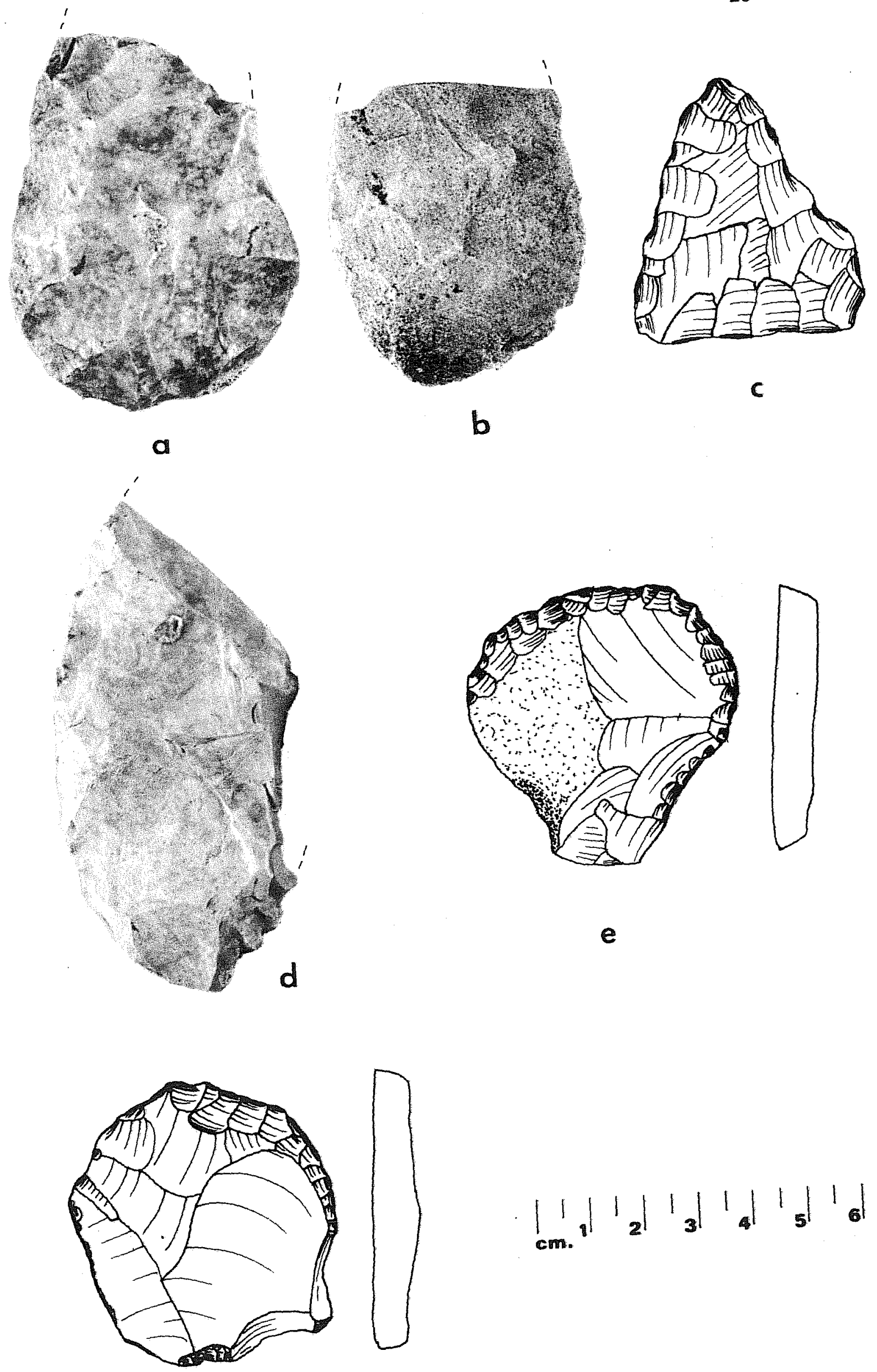
EVALUATION OF RESOURCES

\section{General comments}

The primary aim of this survey was to locate and assess archaeological and historical resources within the areas of proposed SCS projects in the Upper Cibolo Creek Watershed. There were two major considerations influencing our assessments: (1) the significance of the resources to future archaeological and historical studies in the region; (2) the impact of project construction on these resources. Our evaluations are summarized in Tables 2 and 3 . In Table 2, we provide our recommendations regarding the kinds of archaeological investigations that should be carried out at sites in each of the four proposed floodwater retarding structures. At many of the sites, no further work is required. These sites are usually small, with only scattered, surficial archaeological deposits. Once such sites have been documented, surface collected, and their locations plotted, there is little additional information that can be gained through further work. There were, however, a number of sites which need further study. These are sites which apparently have substantial buried deposits and/or extensive surface lithic materials. They could not be adequately assessed during our limited reconnaissance. Some of these sites may be of enough significance to be nominated to the National Register of Historic Places. We simply do not have enough data from our initial survey to warrant such nominations, and it is therefore recommended that such sites receive further "intensive survey". Intensive survey would include mapping of the sites, controlled surface collection, and test excavations. 
Finally, one site ( $41 \mathrm{KE} 49$ ) is of such obvious importance that we believe much valuable archaeological data could be gained through major excavations. This should, however, be preceded by test excavations during the intensive survey phase in order to better plan such future field research at the site.

Table 3 indicates the impact of the proposed floodwater retarding structures on each site. Sites most directly affected are those in the area of the planned dam sites. Construction activities will seriously damage or destroy these resources. At the time of our survey, we did not have information on the placement of borrow pits related to dam construction. Certainly any sites located in these areas will suffer heavily, and archaeologists should inspect these borrow areas prior to fill removal. Table 3 also shows the position of each site in regard to the three major pools within the structure: (1) the 100-year or 50-year sediment pool; (2) the 100-year conservation pool; and (3) the detention pool. Although we can predict that all sites within these three pools will suffer some deleterious effects over the coming decades, the ones most directly affected will be those at low elevation in the sediment pool and the conservation pool. Specific Recommendations

In Floodwater Retarding Structure No. 1, four prehistoric sites will be affected by dam construction. Three of these are minor sites that do not require any further archaeological investigation; another (41 KE 43) should undergo intensive survey prior to the beginning of construction. Of the seven other sites at which no further work is recommended (Table 2), one site (41 KE 37) is a historic cemetery; suggestions regarding as to what measures should be taken (such as 
the moving of graves) to salvage this site are beyond the scope of the present report. Eleven sites in the sediment, conservation, and detention pools and one site, $41 \mathrm{KE} \mathrm{48,} \mathrm{just} \mathrm{above} \mathrm{the} \mathrm{detention}$ pool, should be included in a period of intensive survey in order to better assess their significance. Particular attention should be given during the course of the intensive survey phase to the cluster of sites in the ox-bow area at the western end of the proposed structure. These include sites $41 \mathrm{KE} \mathrm{33,} 41 \mathrm{KE} \mathrm{34,} 41 \mathrm{KE} \mathrm{49,} 41 \mathrm{KE} 50$, $41 \mathrm{KE} \mathrm{52,} 41 \mathrm{KE} \mathrm{53.} \mathrm{The} \mathrm{most} \mathrm{outstanding} \mathrm{site} \mathrm{recorded} \mathrm{during} \mathrm{our}$ initial survey is site $41 \mathrm{KE} 49$. It should be tested during the intensive survey phase, and a large scale program of excavation designed for a later date.

No further work is recommended for sites in Floodwater Retarding

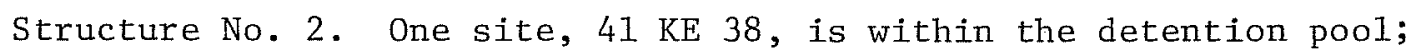
the other two sites lie partially or wholly outside the crest of the maximum detention pool.

In Floodwater Retarding Structure No. 3, it is our opinion that six sites need no further attention. One of these sites (41 KE 59) is along the proposed dam site, two others are above the maximum

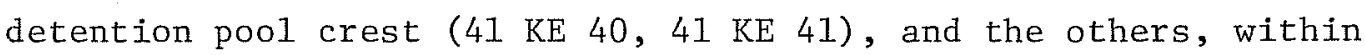
the detention pool ( $41 \mathrm{KE} \mathrm{42,} 41 \mathrm{KE} \mathrm{28,} 41 \mathrm{KE} \mathrm{58).} \mathrm{There} \mathrm{are,} \mathrm{however,}$ three sites within the proposed structure that should be re-examined during the intensive survey phase. These sites (41 KE 46, $41 \mathrm{KE} \mathrm{54,}$ $41 \mathrm{KE} \mathrm{57)}$ are all situated within the detention pool.

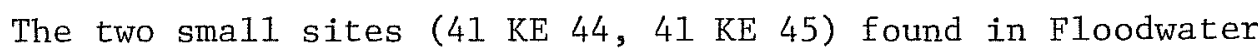
Retarding structure No. 4 do not require any further archaeological study. 


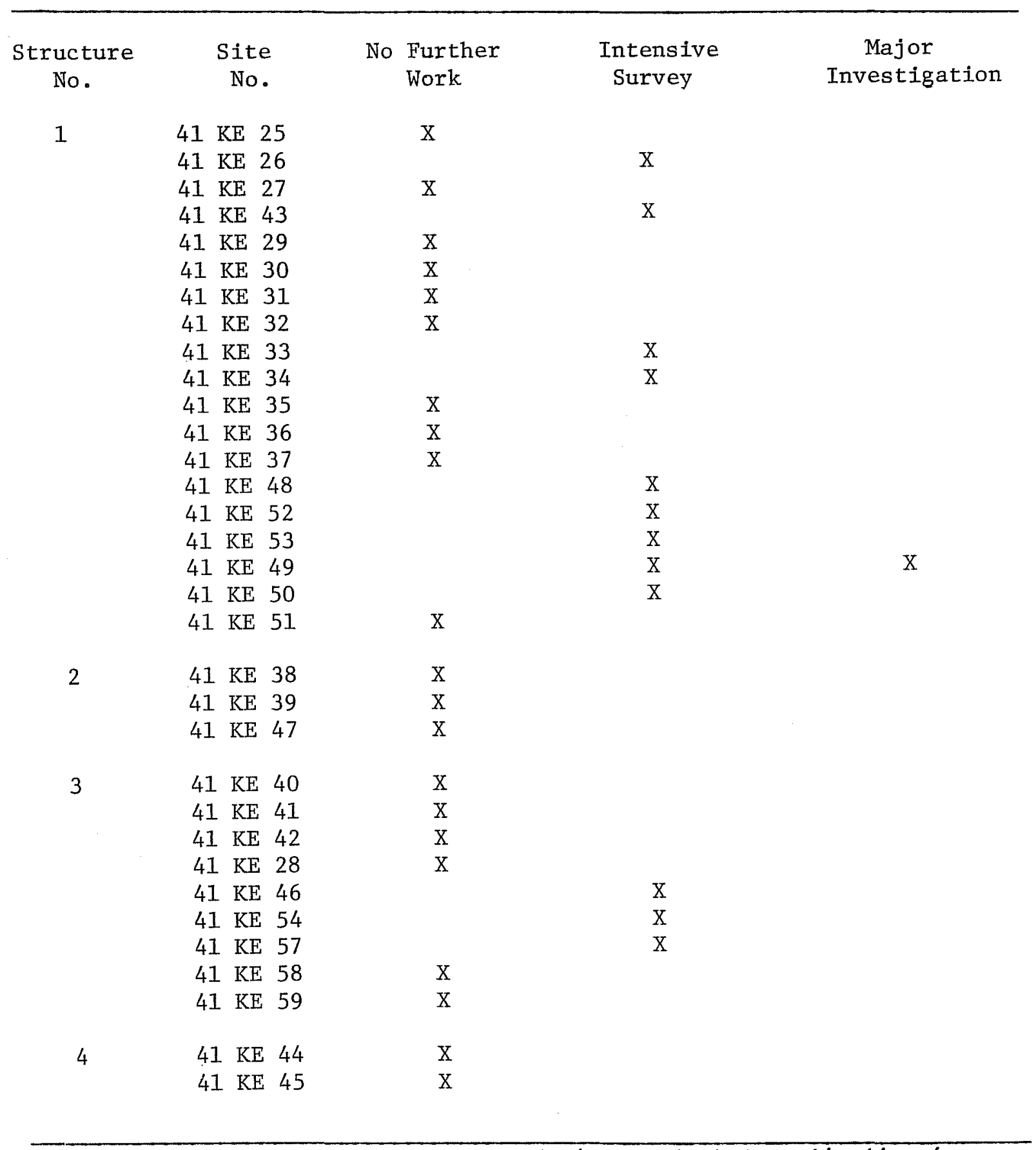

Table 2. Recommendations for Future Archaeological Investigation in the Upper Cibolo Creek Watershed. 


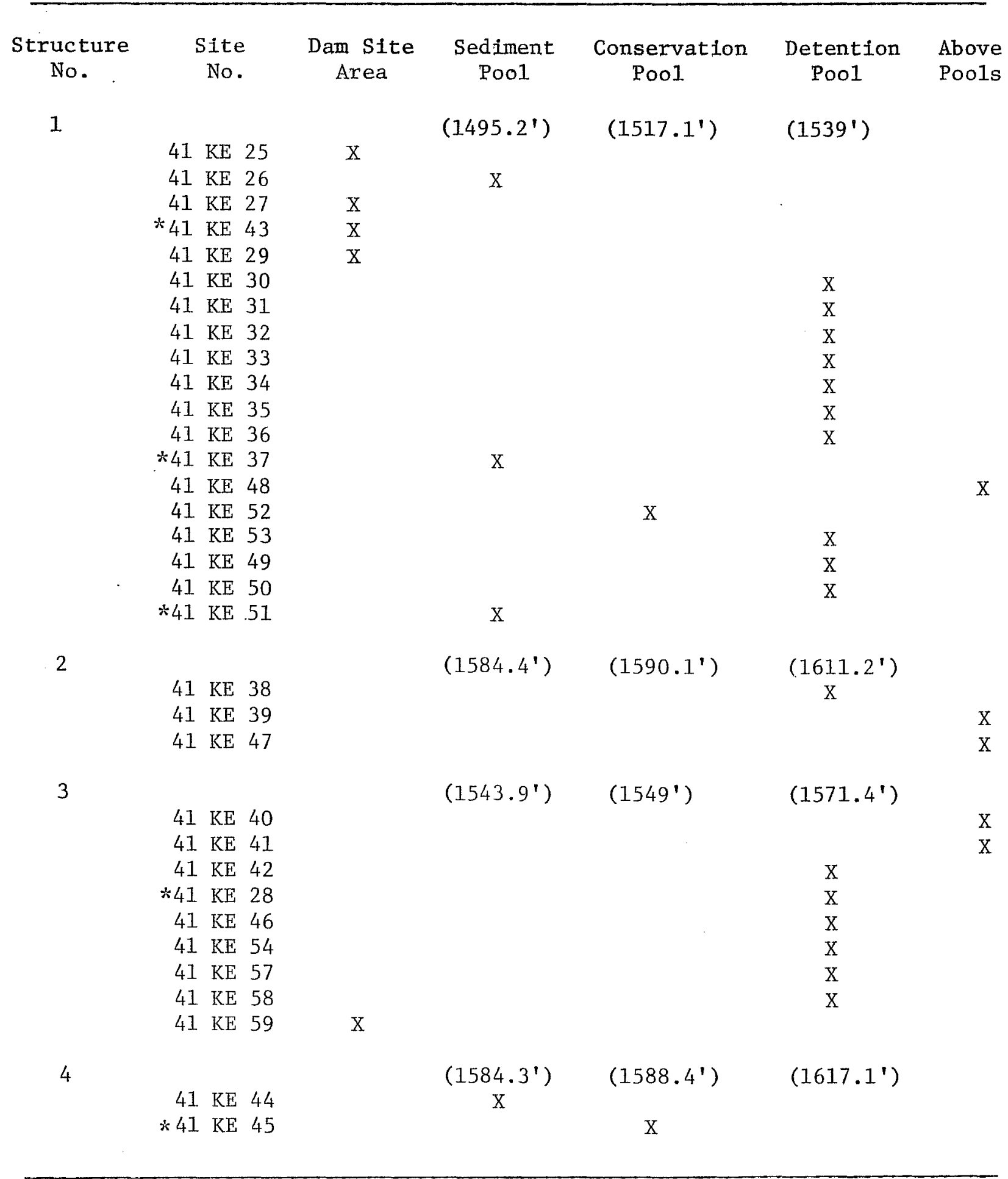

Table 3. Impact of Proposed Floodwater Retarding Structures on Archaeological and Historic Resources. Historic sites are indicated with an asterisk (*). Crest elevations (in feet) are provided for each pool. Sites 1isted in the "Above Pool" column are within project boundaries, except for site $41 \mathrm{KE} \mathrm{40,} \mathrm{which} \mathrm{lies} \mathrm{outside} \mathrm{the} \mathrm{project}$ but in close proximity to the proposed dam site. 
SUMMARY

We have reported here the results of an archaeological survey of four proposed floodwater retarding structures in Kendall County, central Texas. Brief descriptions of the sites, and the artifacts collected from them, have been presented. In addition, we have provided assessments of the sites, evaluated the impact of project construction on the sites, and have made recommendations for further archaeological investigation.

All of the 33 sites appear to date largely from the Archaic era. No evidence of Paleo-Indian occupations were found during this surface reconnaissance. Only one specimen linked to the late prehistoric period was collected (a Fresno point at $41 \mathrm{KE} \mathrm{44).} \mathrm{It} \mathrm{is} \mathrm{possible}$ that additional materials dating from one or both of these periods may be found in the course of future investigations. All three defined units of the central Texas Archaic, Early, Middle, and Late, are represented by diagnostic projectile points and associated lithic materials. Early Archaic specimens include Nolan points from site $41 \mathrm{KE} 43$ and $41 \mathrm{KE} 49$ and a Bulverde point at $41 \mathrm{KE} 40$. Possible Pre-Archaic (Sollberger and Hester 1972) occupations may be inferred from the presence of triangular dart points (termed Tortugas in this report) found at sites $41 \mathrm{KE} 49$ and $41 \mathrm{KE} 50$. The placement of morphologically triangular dart points in a very early phase of the Early Archaic, or perhaps in the postulated Pre-Archaic, has been confirmed by excavations at 41 BX 271 (Granburg II) in Bexar County (cf. Hester and Kohnitz 1975). Middle and Late Archaic occupations are indicated by the occurrence of a number of corner and side notched dart points. 
Functiona11y, a rather limited range of site types is represented in our sample. There are large multi-function open occupation sites, a prime example being $41 \mathrm{KE} \mathrm{49.} \mathrm{Also} \mathrm{present} \mathrm{are}$ a number of somewhat smaller open occupation sites, at which the range of activities can only be determined through controlled surface collection and excavation. These occupation loci exhibit scattered burned rock, hearths, abundant 1ithic debris, and chipped stone tools such as projectile points, unifacial and bifacial implements, and tools in various stages of manufacture.

One site (41 KE 57) is a large burned rock midden. Relic collectors have damaged it extensively, utilizing a bulldozer for part of their pillaging endeavors. However, a substantial part of the midden remains intact, and it is recommended for intensive survey. A partially buried burned rock midden and several surface hearths were noted at $41 \mathrm{KE} 46$.

Another kind of site is quite small and has only a light lithic scatter on the surface ( $41 \mathrm{KE} 41$ and $41 \mathrm{KE} 42$ and examples). Cores and flakes are the main lithic forms collected. Some of these sites may be stone-working loci, temporary hunting and gathering sites, or the focus of some other short-term utilization.

No large quarry-workshop sites were found; Fawcett had noted such a site in the Little Joshua Creek area to the north. It is most likely that these sites are situated at higher elevations, outside the perimeter of our survey areas.

The sites within the project areas are usually found in rather close proximity to the water courses, often on terraces overlooking and paralleling the streams. This site distribution pattern is 
particulary noticeable in Floodwater Retarding Structures 1 and 3, where Cibolo and Frederick Creeks have a weIl developed system of terraces and old elevated floodplains. In both of these areas (Structures 1 and 3) there were a cluster of sites around major ox-bows, the largest number of sites being found on the Cibolo Creek ox-bow. Such a concentration of habitation in these locales may be related to ecological factors, possibly easy access to plant food resources which are naturally concentrated by the two closely spaced north-south arms of the Cibolo ox-bow.

Along the smaller streams, such as Ranger Creek (Floodwater Retarding Structure No. 2) and Deep Hollow Creek (Floodwater Retarding Structure No. 4), sites are located at higher elevations due to the nature of the steep-sided stream valleys. No major occupation sites occurred in either of these two areas.

The abundant prehistoric resources in Floodwater Retarding Structures 1 and 3 will undoubtedly suffer some damage through the construction of these projects and in the subsequent impoundment of water in conservation and detention pools. To better assess the impact that the projects will have on certain of these resources, we conclude this report with a recommendation for a phase of intensive field survey. The survey would allow the archaeologist to determine which sites should be nominated to the National Register of Historic Places, placement on which would necessitate a comprehensive and well designed program of mitigation prior to project completion. The recommended intensive survey of Floodwater Retarding Structure No. 1 would cost approximately $\$ 3,100$, and similar work in Floodwater Retarding Structure No. 3 would necessitate expenditures on the order of $\$ 2,200$. 


\section{REFERENCES CITED}

Blair, W. F.

1950 The Biotic Provinces of Texas. Texas Journal of Science $2(1): \quad 93-116$

Briggs, A.

1970 Preliminary Archaeological Survey of Study Area on the

Guadalupe River. Office of the State Archeologist, Special Reports 13.

Dabney, E. R.

1952 Kendall County. In: The Handbook of Texas (W. P. Webb, ed.), 1: 946 .

Edwards Underground Water District

n.d. The Edwards Underground water District and Edwards Underground Reservoir. San Antonio.

Enlow, D. H. and T. N. Campbell

1955 Some Paleo-Indian Projectile Points from the Southwestern

Periphery of the Great Plains. Panhandle-Plains Historical

Review 28: 29-37.

Godfrey, C. L., G. S. McKee, and H. Oakes, compilers

1973 General Soil Map of Texas. Texas A\&M University, Texas

Agricultural Experiment Station, College Station.

Gould, F. W.

1969 Texas Plants, A Checklist and Ecological Summary. Texas

A\&M Universicy, Texas Agricultural Experiment Station, College Station. 
Hester, T. R. (assembler)

1975 Archaeological and Historical Resources in the San AntonioGuadalupe River Basins: A Preliminary Statement. University of Texas at San Antonio, Center for Archaeological Research, Regional Studies 1.

Hester, T. R., T. C. Kelly and F. A. Bass, Jr.

1975 An Initial Archaeological and Historical Assessment of Three Proposed Dam Sites in Gonzales and Kendall Counties, Texas. University of Texas at San Antonio, Center for Archaeological Research, Regional Studies 2.

Hescer, T. R. and H. Kohnitz

1975 Chronological Placement of "Guadalupe" Tools. La Tierra 2(2): in press.

Jenkins, J. H.

1965 Cracker-Barrel Chronicles. Pemberton Press. Austin. Kocher, A. E. et al

1913 Reconnaissance Soil Survey of South Central Texas. Government Printing office, Washington.

Rose, P. R.

1972 Edwards Group, Surface and Subsurface, Central Texas. Bureau of Economic Geology, University of Texas at Austin, Report of Investigation 74.

Sellards, E. H., W. S. Adkins, and F. B. Plummer

1932 The Geology of Texas. Vol. I. University of Texas Bulletin 3232 .

Sollberger, J. B. and T. R. Hester

1972 The Strohacker Site: A Review of Pre-Archaic Manifestations in Texas. Plains Anthropologist 17 (58): 326-344. 